\title{
Corrosion of Reinforced Concrete Structures Submerged by the 2004 Tsunami in West Aceh, Indonesia
}

\author{
Herdi Susanto, ${ }^{1}$ Syifaul Huzni $\mathbb{D},{ }^{2}$ and Syarizal Fonna $\mathbb{D}^{2}$ \\ ${ }^{1}$ Department of Mechanical Engineering, Faculty of Engineering, Teuku Umar University, Meulaboh 23681 Aceh Barat, Indonesia \\ ${ }^{2}$ Department of Mechanical and Industrial Engineering, Faculty of Engineering, Syiah Kuala University, \\ Darussalam, Banda Aceh 23111, Indonesia \\ Correspondence should be addressed to Syarizal Fonna; syarizal.fonna@unsyiah.ac.id
}

Received 29 January 2018; Revised 3 July 2018; Accepted 9 July 2018; Published 7 August 2018

Academic Editor: Flavio Deflorian

Copyright (C) 2018 Herdi Susanto et al. This is an open access article distributed under the Creative Commons Attribution License, which permits unrestricted use, distribution, and reproduction in any medium, provided the original work is properly cited.

\begin{abstract}
The earthquake and tsunami of 26 December 2004 caused the infrastructure in Aceh's West Coast region to be submerged by seawater and to require the rehabilitation and reconstruction. The infrastructure that was submerged in the tsunami might experience a decrease in strength due to corrosion attack and would unexpectedly collapse if an earthquake occurs even on a small scale. This study was conducted to examine the corrosion risk level of the infrastructures in Aceh's West Coast region, Indonesia, which submerged by the 2004 tsunami. Three locations were chosen for the study, i.e., Suak Ribee, Ujong Kalak, and Padang Seurahet. The assessments were carried out in 2014 and 2015. Three to four columns in each of the buildings were selected for the assessment. The half-cell potential technique method which refers to ASTM C876 was used to obtain and analyze the assessment data. The results of the assessment show that the electrical potentials on the surface of concrete for the buildings which submerged by the tsunami were range between -100 and $-450 \mathrm{mV}$ (vs. $\mathrm{Cu} / \mathrm{CuSO}_{4}$ ) and categorized into low to high corrosion risk level. Meanwhile, the electrical potentials for new buildings range between $(-100)$ and $(-350) \mathrm{mV}$ which indicated low to medium corrosion risk. Hence, the corrosion actively occurred in the areas having medium to high corrosion risk. Also, it was found that the corrosion risk level for the building tends to increase by increasing time. Therefore, the prevention and/or rehabilitation is necessary for stopping the corrosion, and so the premature failure of the building might be avoided.
\end{abstract}

\section{Introduction}

The West Aceh region is vulnerable to catastrophic earthquakes [1]. Meanwhile, there are a large number of infrastructures which were submerged by the 2004 tsunami in the region. The infrastructures were repaired and reused again. Therefore, the infrastructures might be susceptible to corrosion attack $[2,3]$ that can cause a decrease in strength [4], and sudden collapse may happen when an earthquake occurs even on a small scale $[5,6]$. This is certainly not desirable because, besides the material loss, it can also lead to loss of life of people.

To avoid the possibility of a sudden failure of the infrastructures, especially in the regions hit by the 2004 tsunami in West Aceh, corrosion assessment must be done to determine the level of corrosion risk of reinforced concrete infrastructures, and it is important to be performed periodically.
Hence, this study aims to conduct an assessment in order to determine corrosion risk level of reinforced concrete buildings in West Aceh region. For this study, the half-cell potential technique is used by obtaining electrical potential on the surface of the concrete.

\section{Half-Cell Potential Technique}

The half-cell potential technique is a nondestructive test widely used to monitor and determine the corrosion of reinforced concrete infrastructures [7]. Many researchers have performed and justified the method to evaluate the reinforcing steel corrosion in concrete [3,5-8]. Figure 1 shows the comparison of half-cell potential technique result to the actual condition of corrosion from the previous study [5] in which the half-cell potential technique result was consistent with the actual corrosion. This method measures the value 


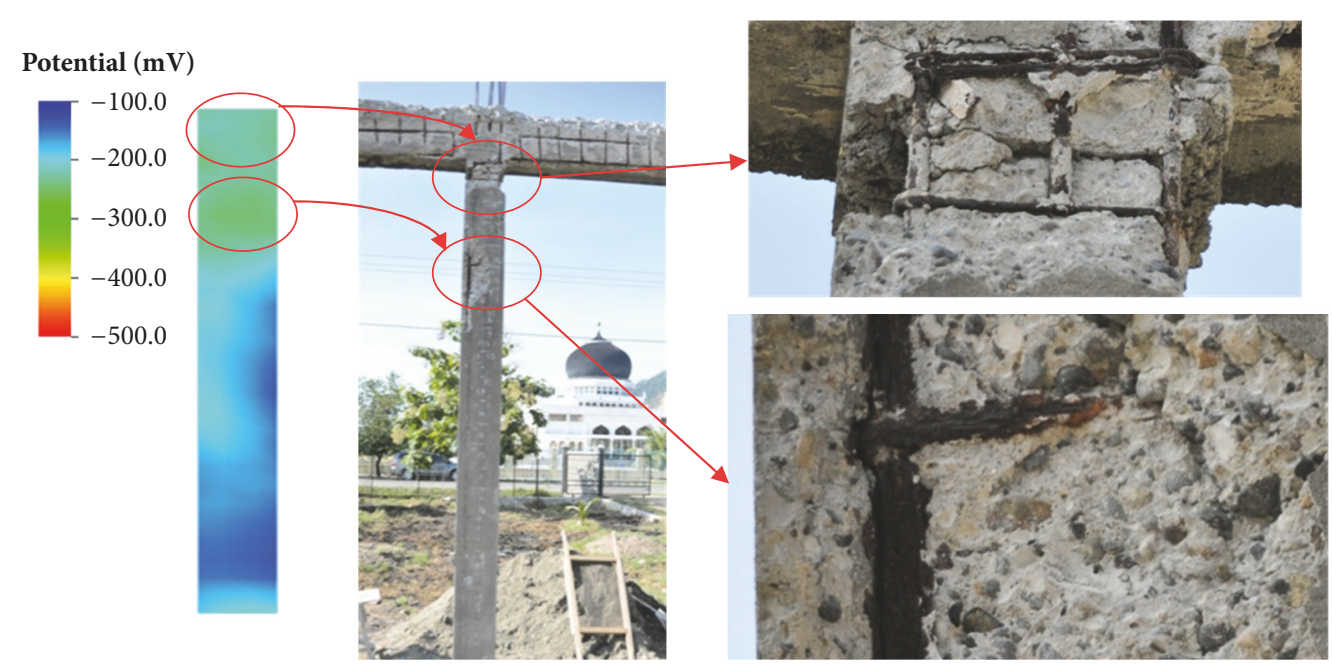

FIGURE 1: Comparison of half-cell potential technique result to the actual corrosion in the previous result [5].

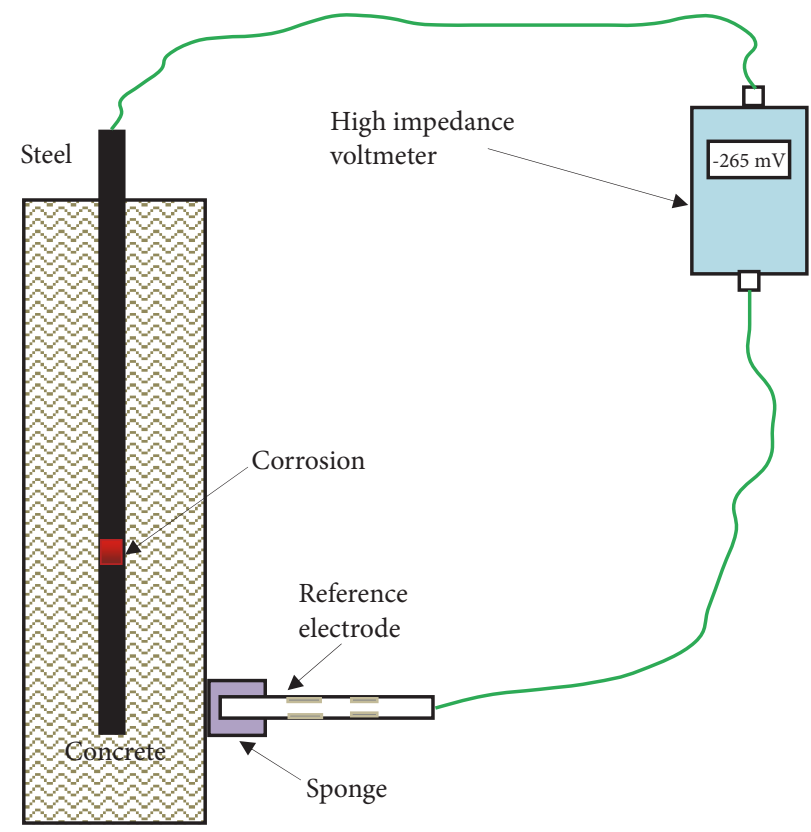

FIGURE 2: Electrical potential measurement with half-cell potential technique.

of electrical potential on the concrete surface in order to determine the level of corrosion risk [4, 9]. ASTM C876 is used as guidance in performing the half-cell potential technique and a criterion to analyze the electrical potential data [4]. Figure 2 shows the schematic of electrical potential measurement on the concrete surface which performed using the methods and Table 1 shows the criteria for the levels of corrosion risk.

\section{Corrosion Assessment of the Reinforced Concrete Structures}

This assessment was carried out in the region hit by the 2004 tsunami, especially West Aceh Regency. Three locations were selected in the regions, i.e., Suak Ribee (Objects I and III), Padang Seurahet (Object II), and Ujung Kalak (Object IV).

The first study was conducted in August 2014 and the second in June 2015. Two reinforced concrete buildings that submerged by the tsunami (Objects I and II) and two new buildings built after the 2004 tsunami (Objects III and IV) were selected in this study. The locations of the buildings/ objects can be seen in Figure 3. The main equipment for the study was half-cell meter and rebar locator as shown in Figure 4.

Then, for every building, at least three columns were selected to be measured to their corrosion potential. On each column, the location of the reinforcement was determined with the rebar locator. Then, a grid was constructed on the 
TABLE 1: Criteria for corrosion risk levels with referring to ASTM C876 [4].

\begin{tabular}{cccccc}
\hline \multirow{2}{*}{ No } & \multicolumn{2}{c}{ Reference Electrode $(\mathbf{m V})$} & Corrosion risk level \\
& $>(-200)$ & $\mathbf{A g} / \mathbf{A g C l}$ & Standard Hydrogen & Calomel & Low (10\% risk of corrosion) \\
\hline 1 & $(-200)-(-350)$ & $(-100)-(-250)$ & $(+120)-(-30)$ & $(-80)-(-230)$ & Intermediate corrosion risk \\
\hline 2 & $<(-350)$ & $<(-250)$ & $<(-30)$ & $<(-230)$ & High $(>90 \%$ risk of corrosion) \\
\hline 3 & $<(-500)$ & $<(-400)$ & $<(-180)$ & $<(-380)$ & Severe corrosion \\
\hline 4 & & &
\end{tabular}

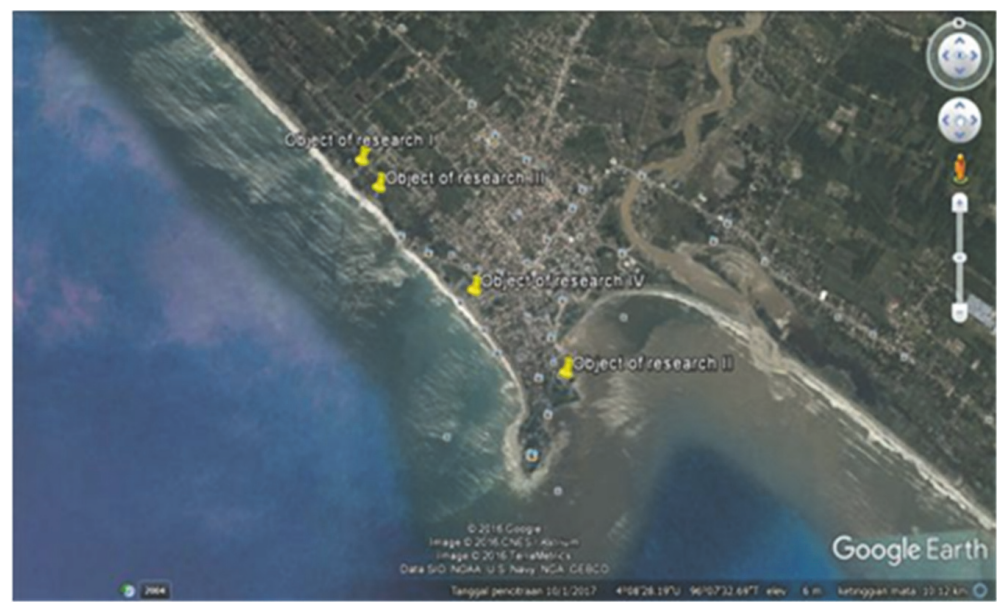

FIGURE 3: The locations of the reinforced concrete building for the study.

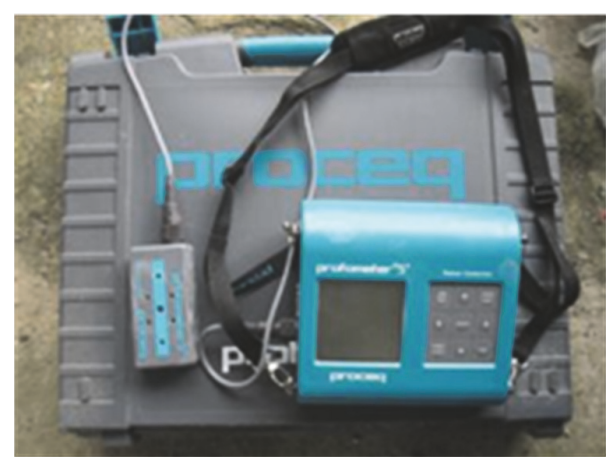

(a)

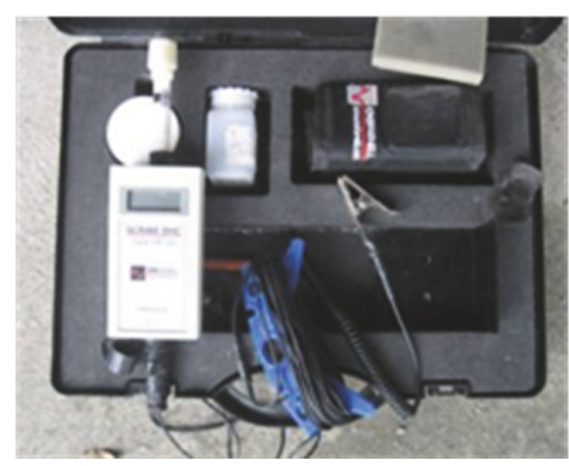

(b)

FIGURE 4: (a) Rebar locator (profometer $5^{+}$) and (b) SCRIBE DHC digital half-cell meter.

surface of the column corresponding to the location of the reinforcement. The four buildings are shown in Figures 5 and 6.

Next, the four buildings were assessed for their corrosion risk levels. Every column for buildings to be assessed was shown in Figures 7 and 8. The measurement of rebar location using profometer can be seen in Figure 9(a). Meanwhile, the potential corrosion measurement was shown in Figure 9(b).

\section{Result and Discussion}

The potential corrosion data which were obtained on the reinforced concrete structure were mapped using the software
VisIt-2.7.3. The software is an open source. It used to generate color contour represented potential values on the columns of the building.

Figure 10 shows the corrosion risk assessment results for Object I in Suak Ribee submerged by the 2004 tsunami. The potential distributions on four columns were presented in the figure. The potential distribution of year 2014 for column 1, column 2 , column 3 , and column 4 ranged between $(-100)$ and $(-350) \mathrm{mV},<-200 \mathrm{mV},(-200)$ and $(-350) \mathrm{mV}$, and $(-100)$ and $(-$ $450) \mathrm{mV}$, respectively, while those potential distributions of the columns ranged between $(-200)$ and $(-350) \mathrm{mV},(-200)$ and $(-350) \mathrm{mV},(-200)$ and $(-350) \mathrm{mV}$, and $(-200)$ and $(-350)$ $\mathrm{mV}$, respectively, of year 2015 . 


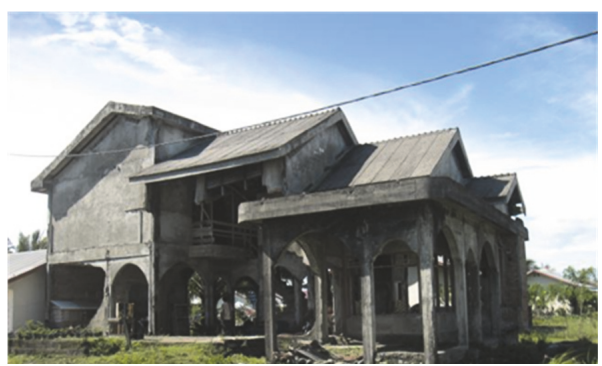

(a)

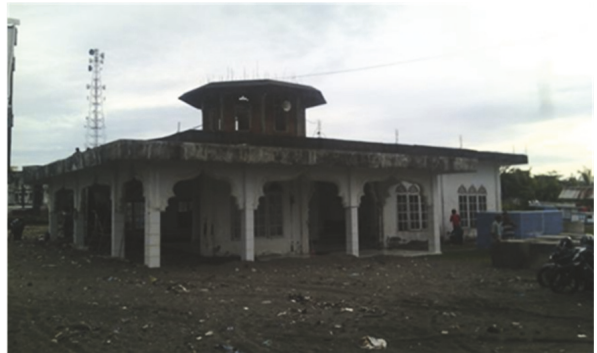

(b)

FIGURE 5: Buildings submerged by the tsunami: (a) Objects I and (b) Object II.

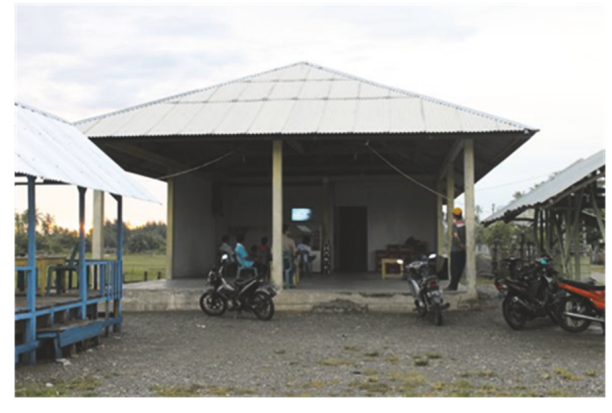

(a)

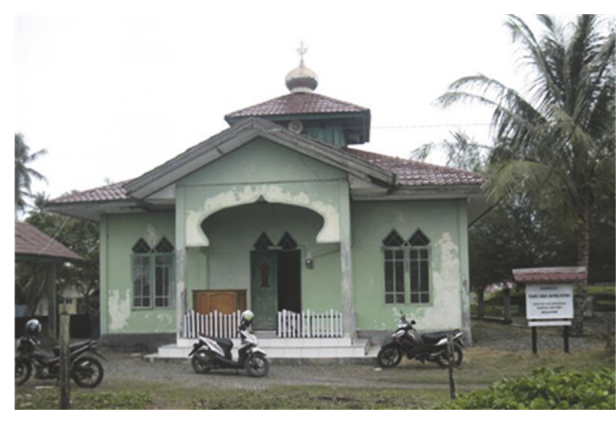

(b)

Figure 6: New buildings: (a) Objects III and (b) Object IV.

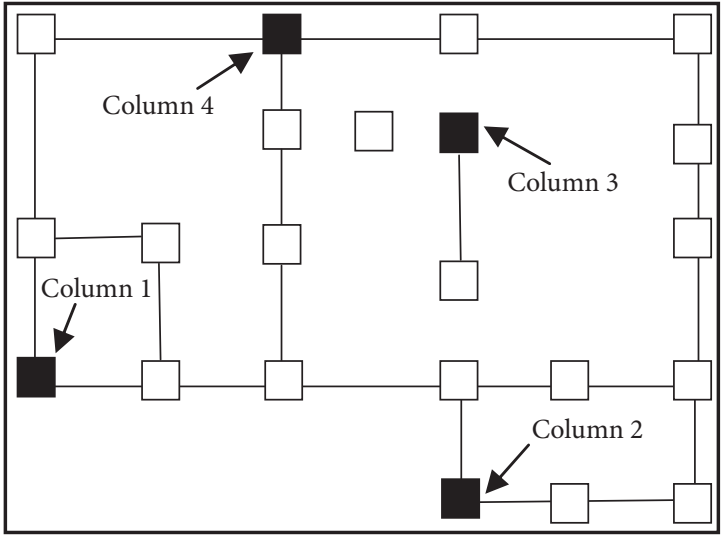

(a)

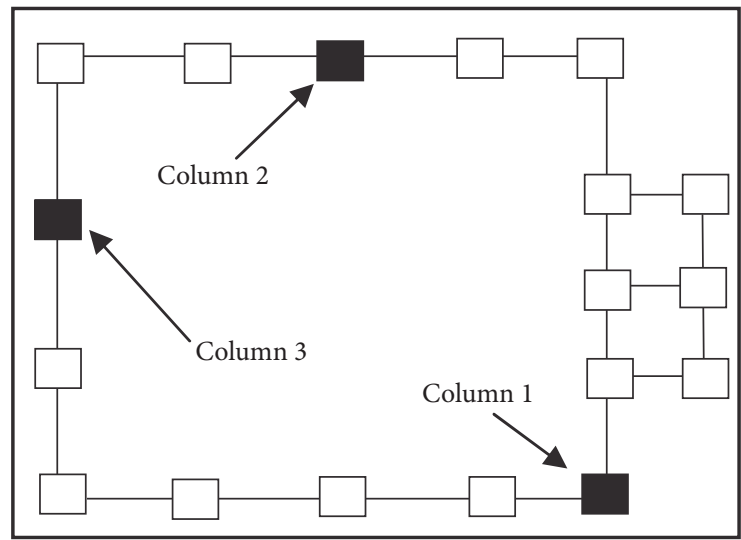

(b)

FIGURE 7: Schematic sketch for (a) Object I and (b) Object II.

Referring to Table 1, the distribution of the potentials on the columns indicated that the corrosion risk level varied from low to high-risk level. Some parts of column 1 (especially lower part), column 2, and lower part column 4 were categorized into low corrosion risk level for the year 2014. In 2015, the corrosion risk level for those parts became intermediate risk level. The corrosion risk level for column 3 was intermediate risk level in 2014 and remained at this level in 2015. The high-risk level occurs in column 4. However, it became intermediate risk level in 2015. It might happen due to repassivation on the rebar. However, further study is needed.
The increasing of corrosion risk level of the columns was consistent with the previous study conducting the half-cell potential mapping in Banda Aceh city, Indonesia [6] as seen in Figure 11(a). The indication of repassivation also occurred in the previous study that was shown in Figure 11(b) [6]. However, the corrosion risk generally tends to become higher by increasing the time for all columns in this study and also in the previous study [6].

Another assessment result for infrastructure submerged by the 2004 tsunami was given in Figure 12. The figure shows the corrosion risk assessment results for Object II in Padang 


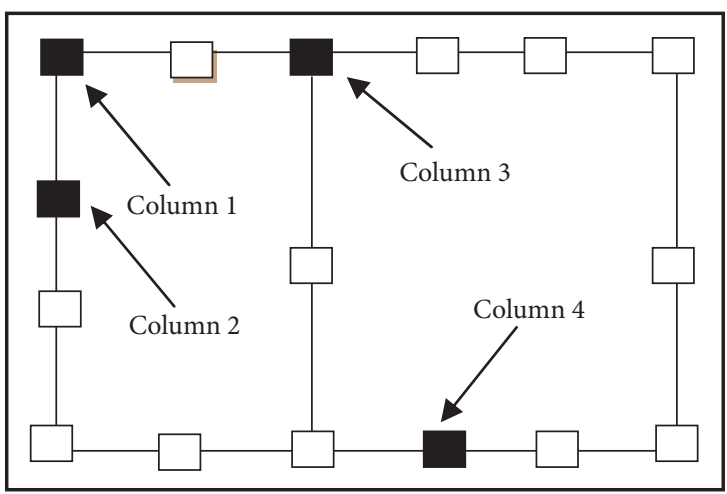

(a)

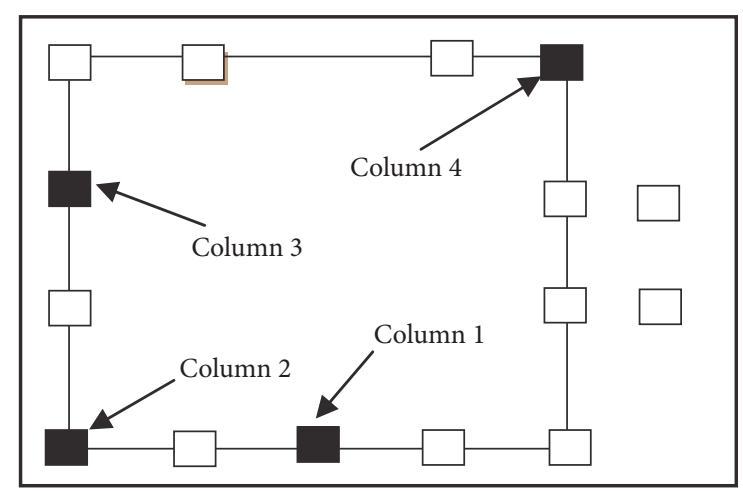

(b)

FIGURE 8: Schematic of column position of (a) Object III and (b) Object IV.

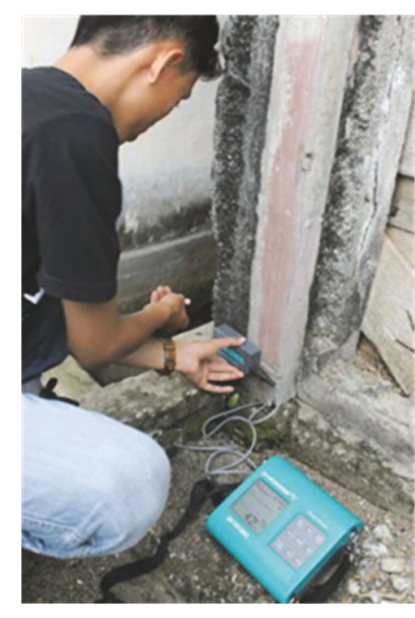

(a)

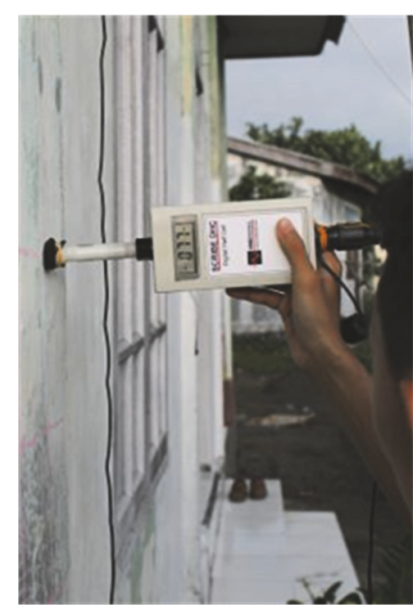

(b)

FIGURE 9: (a) Measurement of the location of steel reinforcement and (b) potential corrosion measurement of the column.

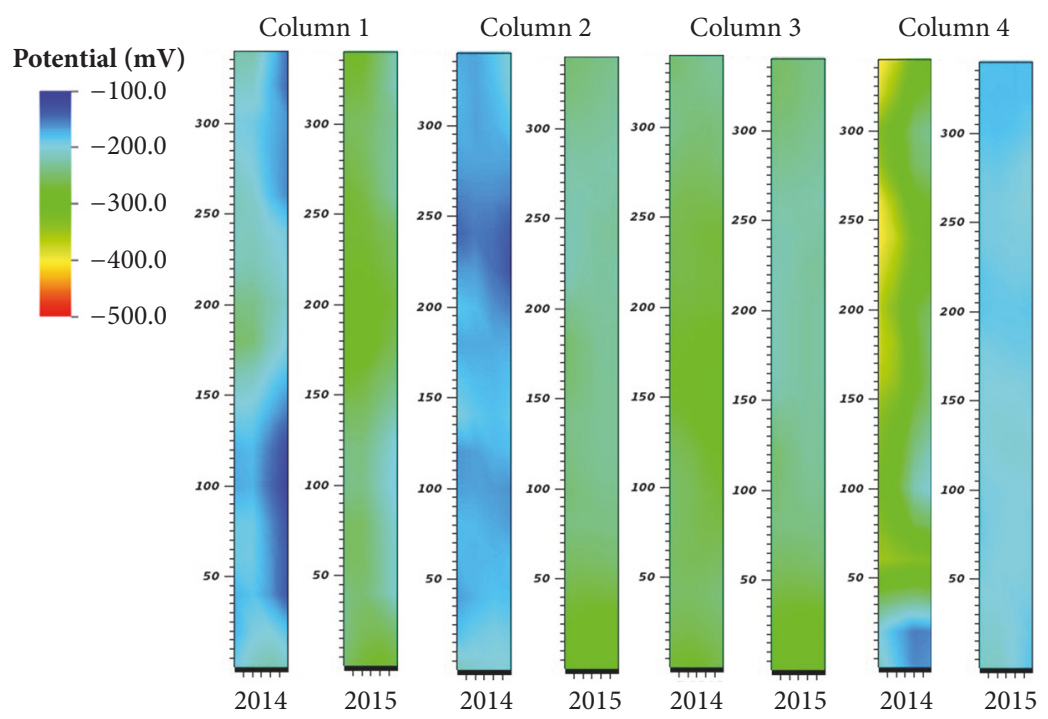

FIgURE 10: The potential distribution on each column of Object I for 2014 and 2015. 


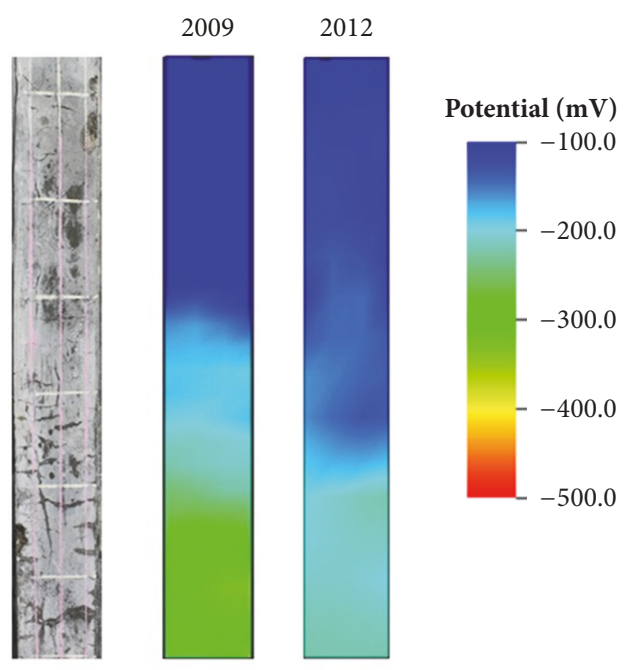

(a)
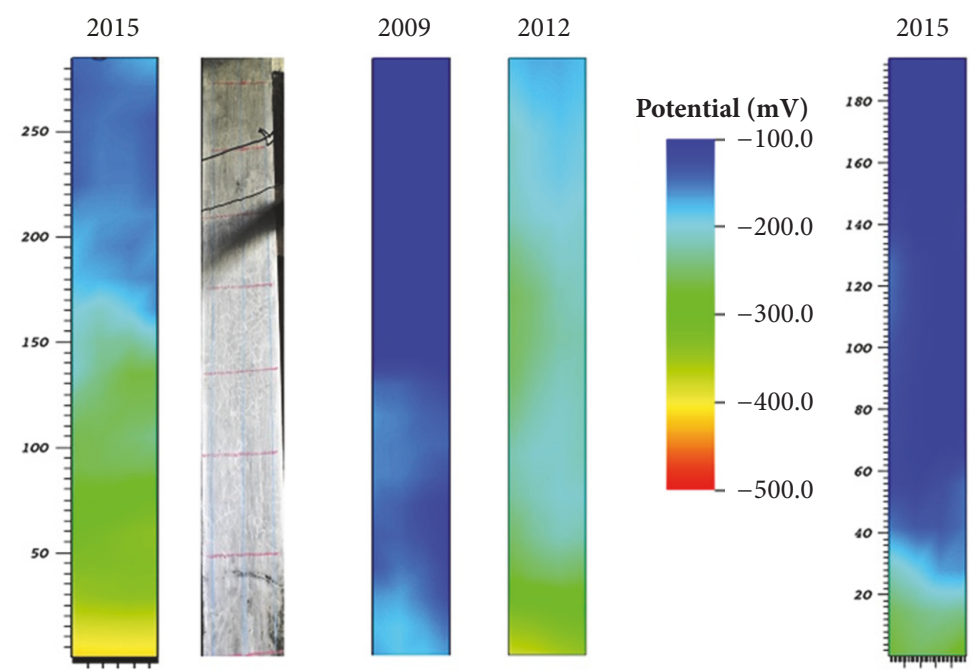

(b)

Figure 11: The potential distribution on the column for the previous study in Banda Aceh city, Indonesia: (a) indicating an increase of corrosion risk and (b) indicating repassivation [6].
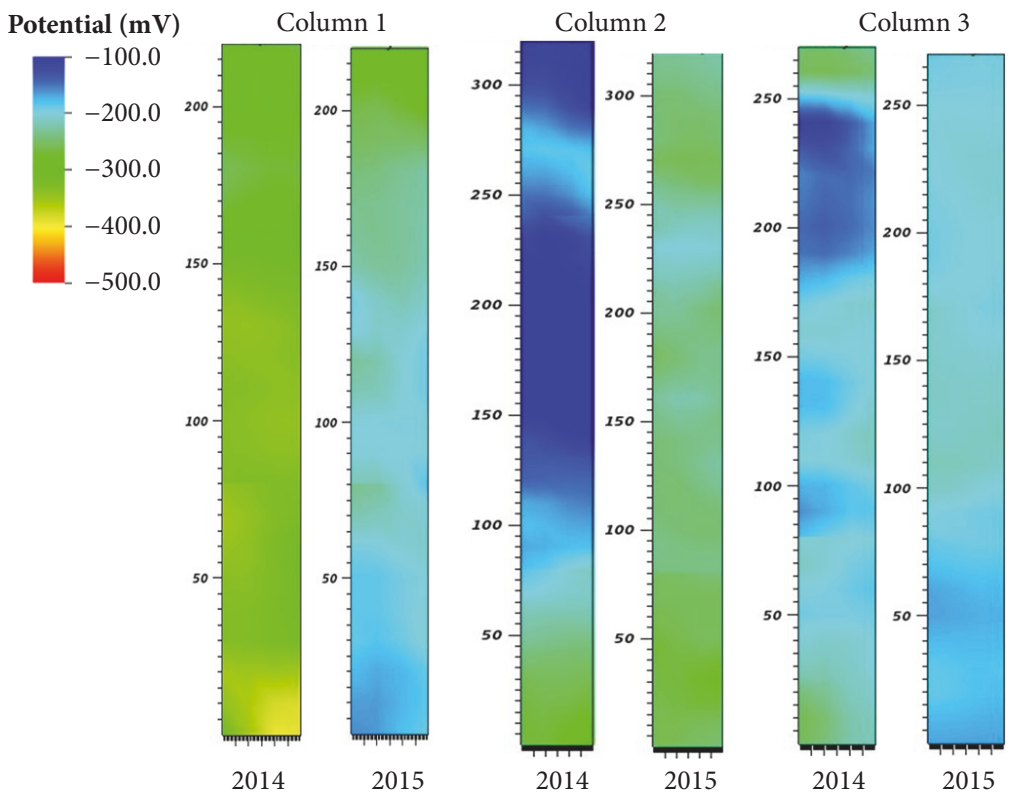

FIGURE 12: The potential distribution on each column of Object II for 2014 and 2015.

Seurahet. In 2014, the potential distribution for column 1, column 2, and column 3 ranged between $(-200)$ and (450) $\mathrm{mV},(-100)$ and $(-350) \mathrm{mV}$, and $(-100)$ and $(-350) \mathrm{mV}$, respectively. Thus, those potential distributions became in range between $(-200)$ and $(-350) \mathrm{mV},(-200)$ and $(-350) \mathrm{mV}$, and $(-200)$ and $(-350) \mathrm{mV}$, respectively for 2015 .

Using the criteria in Table 1, the potential on the columns of Object II was categorized into low to high corrosion risk level. Almost all of column 1 had completely fallen into intermediate corrosion risk, but the lower part was already at high corrosion risk level in 2014. However, the data in 2015 show that the potential value became less negative but is still into intermediate corrosion risk level. The corrosion risk level for columns 2 and 3 falls into low and intermediate risk level in 2014. Thus, it completely became intermediate corrosion risk in 2015.

The phenomenon that the corrosion worsened by increasing time can be confirmed by looking at Figure 13. The figure shows the visual of a column condition of the year 2014 and 2015. Initially, there were cracks on the column in 2014, and the cracks became bigger and longer in 2015. Furthermore, the corroded rebar was also revealed in 2015. It occurred because the corrosion product will push the concrete cover with the load over the strength of concrete and so the crack might be initiated [10]. Finally, by increasing time, the concrete cover might collapse completely. 


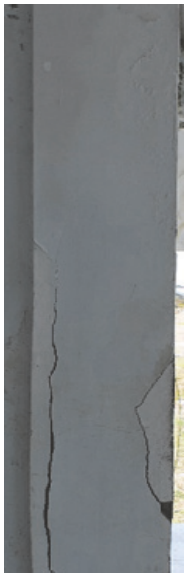

(a)

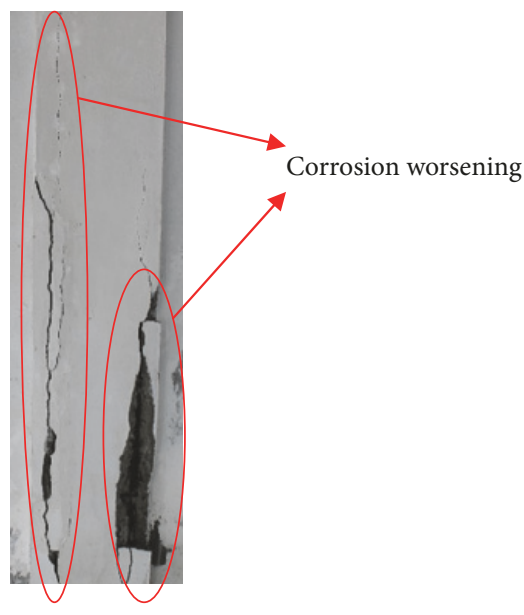

(b)

FIgURE 13: The visual of a column of Object II for (a) 2014 and (b) 2015.

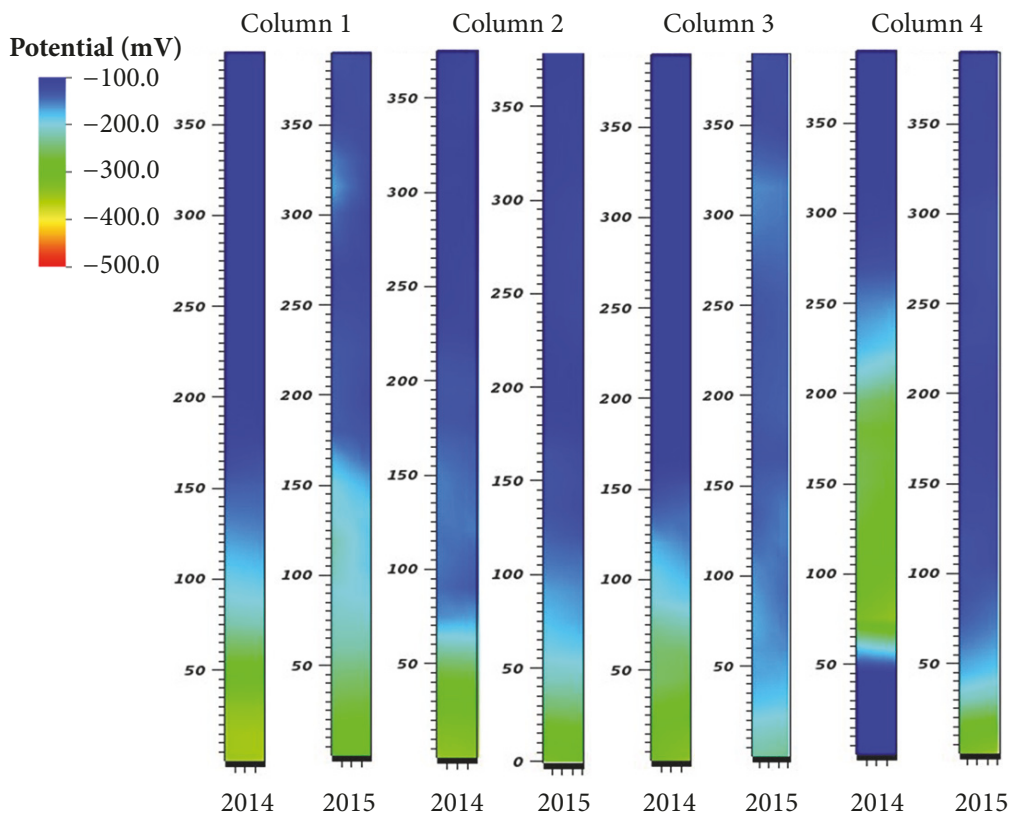

FIgURE 14: The potential distribution on each column of Object III for 2014 and 2015.

Moreover, the potential distribution for one of the infrastructures built in the tsunami-affected area (Object III) was shown in Figure 14. As mention before, this building is located in Suak Ribee. In 2014, the potential distribution for column 1, column 2 , column 3 , and column 4 was the same, i.e., ranging between $(-100)$ and $(-350) \mathrm{mV}$. Thus, it was found that those potential distribution values remain the same in 2015, i.e., $(-100)$ and $(-350) \mathrm{mV}$. However, there was difference in the potential distribution pattern comparing the 2014 data with the 2015 data.

The potential values on the columns of Object III might be categorized into low to intermediate corrosion risk level by referring to the criteria in Table 1 . The majority of the columns lower part had completely fallen into intermediate corrosion risk but the upper parts were at low corrosion risk level in 2014. However, it was found that an area on the lower part of column 4 is still in low-risk level. The data in 2015 show that the potential values for all columns tend the same. The corrosion risk level for all columns lower part falls into intermediate risk level and the upper parts are still at low-risk level. Thus, the lower parts of columns seem more susceptible to corrosion. This might be due to the capillarity of concrete that the lower part could obtain more water from the soil and/or rainwater than others part of the column. Hence, the possibility of corrosion to initiate becomes higher.

Furthermore, by conducting a visual inspection, it was found that there was a difference on the condition between the column directly facing the sea and the column facing the 


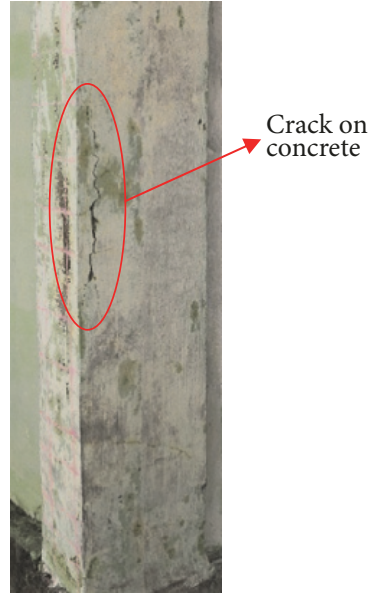

(a)

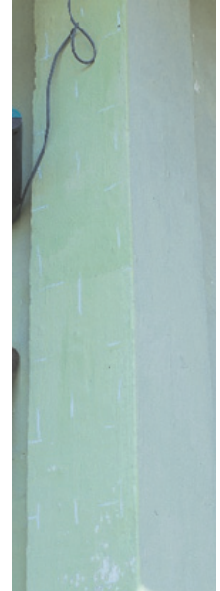

(b)

FIGURE 15: The visual of a column of Object III for (a) directly facing to the sea and (b) facing to the opposite of sea.

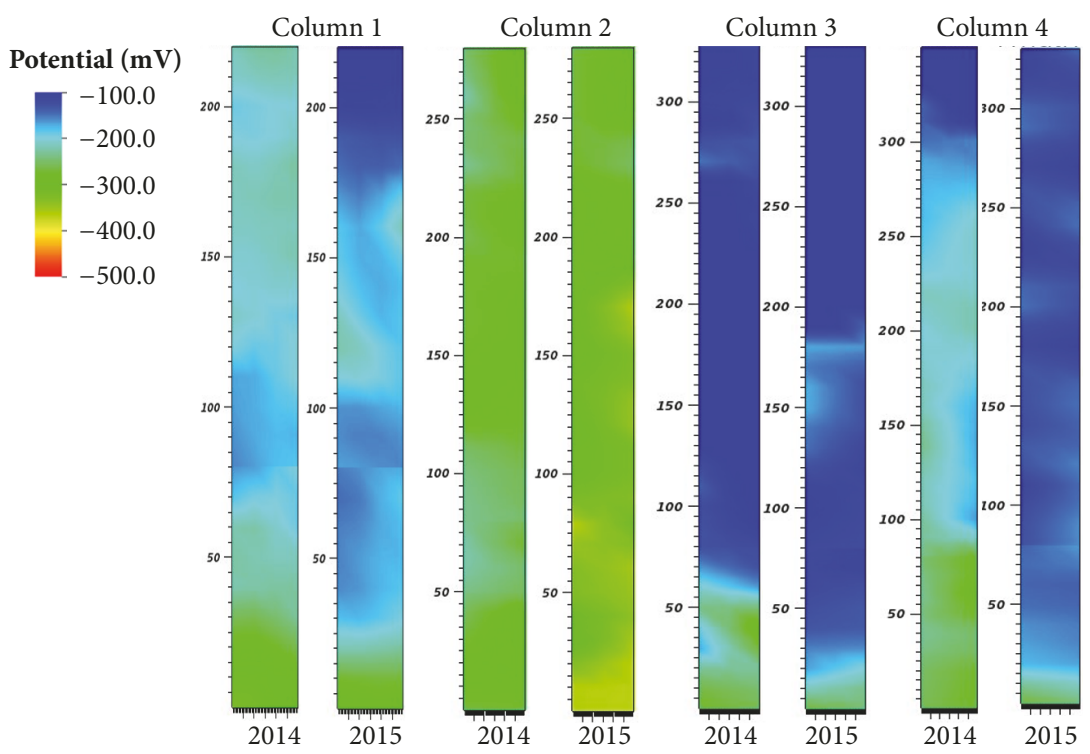

FIGURE 16: The potential distribution on each column of Object IV for 2014 and 2015.

opposite direction of the sea as seen in Figure 15. The figure shows that the column facing the sea already has a crack on it. The crack was an indication that the corrosion actively occurs [10] below the concrete surface at the region. This condition might happen due to the ion chloride more accumulated on the concrete. The ion chloride could be carried by the wind from the sea [11]. It was consistent with the previous research that the ion chloride content in the rainwater around the coastal area was relatively high (24 ppm) [12].

The potential distribution for the last infrastructures was shown in Figure 16. This building was built in the tsunamiaffected area (Object IV) and located in Ujong Kalak. In 2014, the potential distribution for column 1, column 2, column 3 , and column 4 ranged between $(-200)$ and $(-350) \mathrm{mV}$, ($200)$ and $(-450) \mathrm{mV},(-100)$ and $(-350) \mathrm{mV}$, and (-100) and ($350) \mathrm{mV}$, respectively. Thus, it was found that those potential distribution values for column 1 tend to become more positive in 2015 , i.e., $(-100)$ and $(-350) \mathrm{mV}$. The potential on column 2 became more negative in 2015, i.e., (-300) and $(-450) \mathrm{mV}$. Lastly, the potential values for column 3 and column 4 tend to be more positive but remain in the same range in 2015, i.e., $(-100)$ and $(-350) \mathrm{mV}$.

Based on the criteria in Table 1, the corrosion risk level for the columns could be determined. The corrosion risk level for column 1 and column 2 was already at intermediate risk in 2014. In 2015, the risk level tends to become higher for column 2. The below part was at a high-risk level. This condition was suspected because of the position of column 2 directly facing the sea and, thus, it might be more exposed to ion chloride from the sea. However, the upper part of column 1 became low-risk level in 2015, while the corrosion risk level for column 3 and column 4 was relatively the same at intermediate risk for 2014 and 2015. 
By comparing the assessment results of the 2014 and 2015 data, a tendency of increasing the negativity of corrosion potential values is shown. This means that the corrosion actively occurred on the reinforcing steels. Furthermore, this shows that the new structures built in the tsunami-affected area would be susceptible to corrosion attack indicated by its intermediate corrosion risk level. These results were consistent with assessment results conducted around Banda Aceh city [6]. Therefore, it is important to take action to stop the corrosion, so the sudden failure of the structures could be prevented.

\section{Conclusion}

The corrosion risk assessment based on ASTM C876 has been conducted for four infrastructures in West Aceh Regency, Aceh Province, Indonesia. The results show that some parts of the structures were already at intermediate to high corrosion risk level. The structures that submerged by the 2004 tsunami show the tendency at higher risk than the structures built after the 2004 tsunami. However, these structures are also already at intermediate corrosion risk level. This indicated that the corrosion actively occurs for all infrastructures. Hence, the rehabilitation and/or protection is necessary to be carried out in order to prevent the corrosion worsening and so the premature failure might be avoided.

\section{Data Availability}

The data used to support the findings of this study are available from the corresponding author upon request.

\section{Conflicts of Interest}

The authors declare that they have no conflicts of interest.

\section{References}

[1] Pemerintah Aceh, Rencana Pembangunan Jangka Panjang (RPJP) Aceh Tahun 2012-2032, Indonesian, 2012, https://bappeda .acehprov.go.id/download/download/24.

[2] NACE, "Corrosion cost by industrial sector," Supplement to Material Performance, vol. 41, no. 7, p. 4, 2006.

[3] R. R. Hussain, "Underwater half-cell corrosion potential bench mark measurements of corroding steel in concrete influenced by a variety of material science and environmental engineering variables," Measurement, vol. 44, no. 1, pp. 274-280, 2011.

[4] J. P. Broomfield, Corrosion of Steel in Concrete - Understanding, Investigation and Repair, Taylor \& Francis, London, UK, 2nd edition, 2007.

[5] M. Ridha, S. Fonna, S. Huzni, and A. K. Ariffin, "Corrosion risk assessment of public buildings affected by the 2004 tsunami in Banda Aceh," Journal of Earthquake and Tsunami, vol. 7, no. 1, pp. 1-22, 2013.

[6] S. Fonna, M. Ridha, S. Huzni, W. A. Walid, T. D. Mulya, and T. A. K. Ariffin, "Corrosion risk of RC buildings after ten years the, 2004, tsunami in banda aceh - Indonesia," Procedia Engineering, vol. 171, pp. 965-976, 2017.
[7] V. Leelalerkiet, J.-W. Kyung, M. Ohtsu, and M. Yokota, "Analysis of half-cell potential measurement for corrosion of reinforced concrete," Construction and Building Materials, vol. 18, no. 3, pp. 155-162, 2004.

[8] T. Parthiban, R. Ravi, and G. T. Parthiban, "Potential monitoring system for corrosion of steel in concrete," Advances in Engineering Software, vol. 37, no. 6, pp. 375-381, 2006.

[9] ASTM C876-91, "Standard Test Methods for Half-Cell Potentials of Uncoated Reinforcing Steel in Concrete, Wear and Erosion; Metal Corrosion," Vol. 03.02, August 2005.

[10] C. Jiang, Y.-F. Wu, and M.-J. Dai, "Degradation of steel-toconcrete bond due to corrosion," Construction and Building Materials, vol. 158, pp. 1073-1080, 2018.

[11] L. J. Korb and D. L. Olson, ASM Handbook: Corrosion, vol. 13, ASM International, 1992.

[12] I. Musalam and R. Nasoetion, "Penelitian karakteristik korosi atmosfer di daerah pantai utara jakarta," Korosi, vol. 14, no. 1, pp. 1-8, 2005, in Indonesian. 


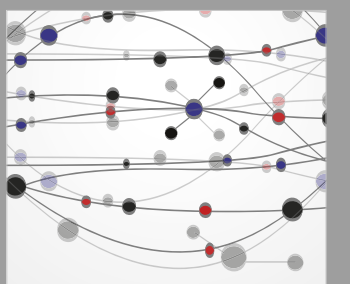

The Scientific World Journal
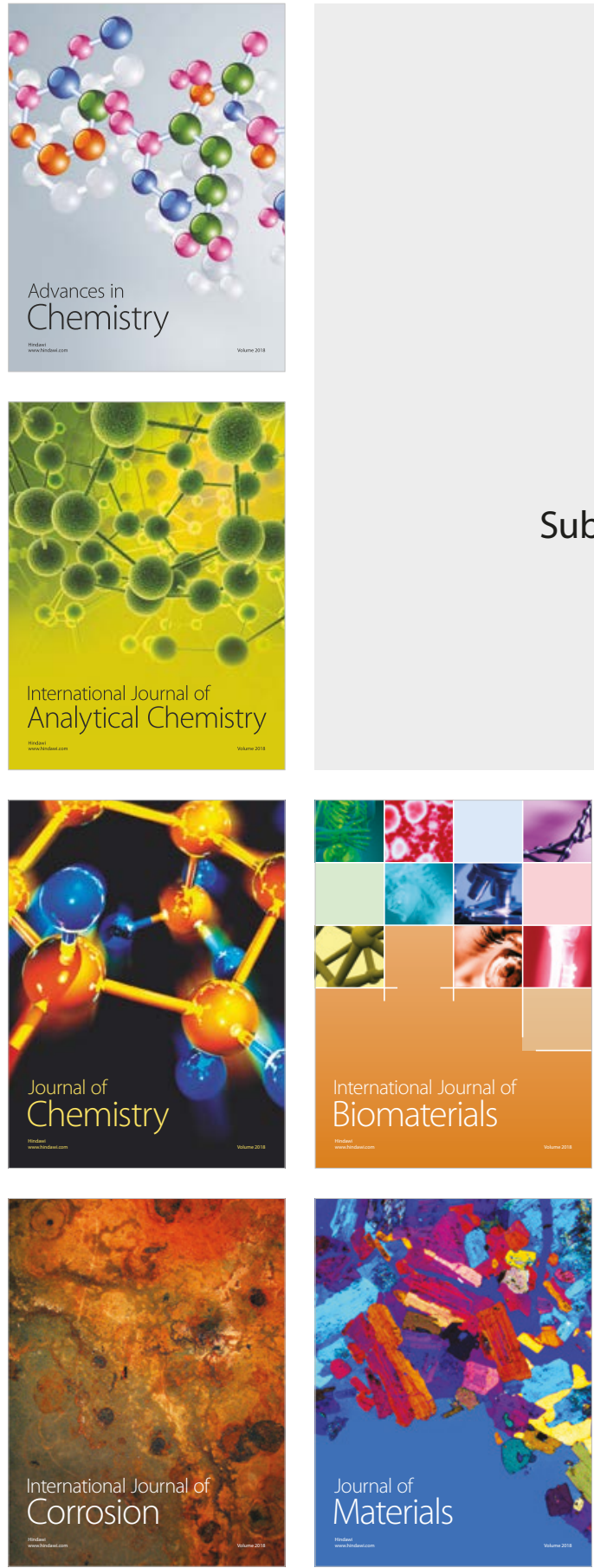

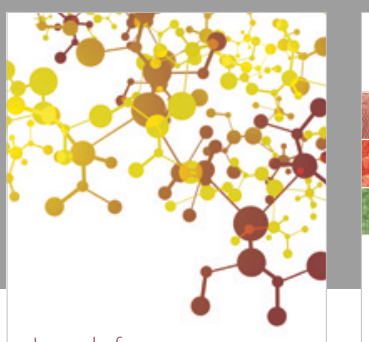

Journal of

Applied Chemistry
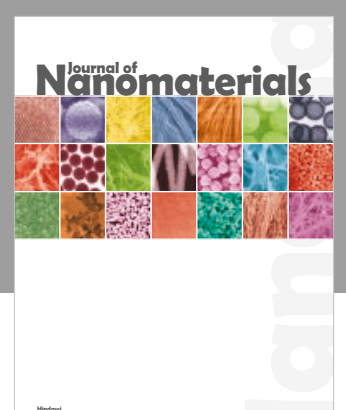

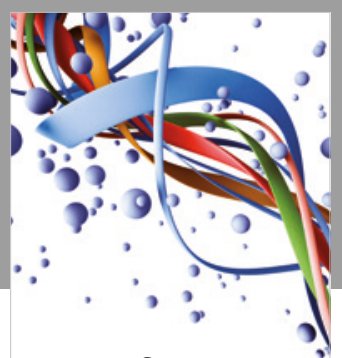

Scientifica

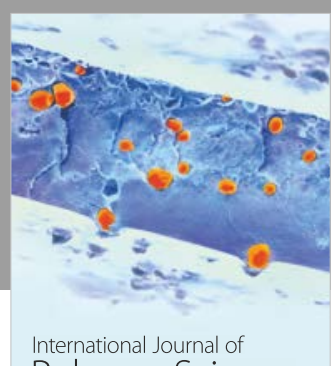

Polymer Science

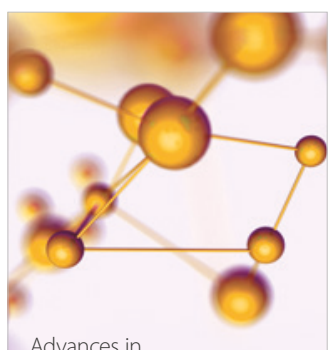

Physical Chemistry
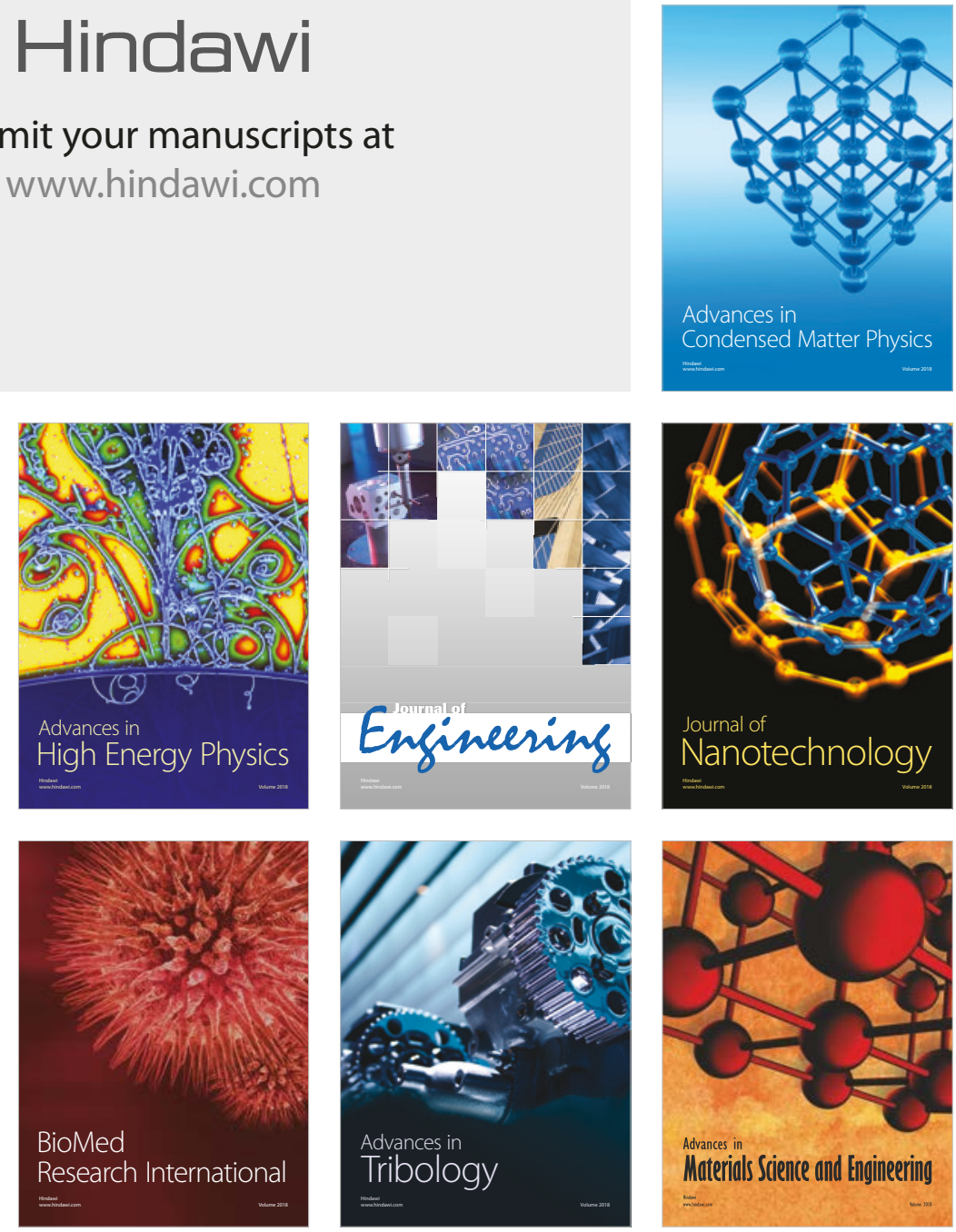